\title{
The efficiency of control of the number of Helicoverpa armigera Hbn. in sunflower sowings
}

\author{
Sergey Semerenko ${ }^{1}$, and Nadezhda Bushneva ${ }^{1, *}$ \\ ${ }^{1}$ V.S. Pustovoit All-Russian Research Institute of Oil Crops, 17 Filatova street, 350058 Krasnodar, \\ Russia
}

\begin{abstract}
The insect Helicoverpa armigera Hbn. (Lepidoptera: Noctuidae) is a widespread species in the Palearctic. It is considered one of the main pests of many agricultural crops, annually causing more than $\$ 2$ billion of losses to agriculture in the world. Therefore, insecticide treatment of sowings is crucial in pest control. The frequent application of pesticides increases resistance in insects, resulting in an increase in dosage and (or) in the usage of new highly toxic chemicals. Consequently, the search for reliable means of pest control remains a problem. In 2017-2019, we studied the efficiency of insecticides against $H$. armigera in sunflower sowings at V.S. Pustovoit All-Russian Research Institute of Oil Crops (Krasnodar). In 2017, the colonization of sunflower heads with $H$. armigera caterpillars was at the level of 3.2 specimen/plant, in $2018-4.5$ specimen/plant, in 2019 it reached 6.0 specimen/plant. Bifetrin + Chlorpyrifos, EC (87\%) and Chlorantraniliprole, SC (91\%) showed the highest biological efficiency. Fitoverm-M, EC was the best organic insecticide - $56 \%$. The treatment of sunflower plants with Betacypermethrin + Dimethoate, EC (standard) and Chlorantraniliprole, SC in a production experiment contributed to a significant decrease in the number of caterpillars -71.7 and $97.0 \%$, respectively. The yield reliably exceeded the control one, the kept yield was $0.23-0.39 \mathrm{t} / \mathrm{ha}$.
\end{abstract}

\section{Introduction}

The insect Helicoverpa armigera Hbn. (Lepidoptera: Noctuidae) is a widespread species in the Palearctic. Every year, its range expands and over the past decade the insect has already begun to appear in several countries of Latin and Central America [1-3].

The $H$. armigera caterpillars feed on 300 plant species, including agricultural commercially important crops, and cause more than $\$ 2$ billion of losses to agriculture in the world [4, 5]. In the Russian Federation, phytophage caterpillars inhabit 120 plant species. Most of all they harm tomato, corn, soybean, and sunflower [6]. In agriculture of the Krasnodar region, sunflower is considered the main oil crop, the annual yield losses from $H$. armigera damage reach $35 \%$. The damage increases from indirect damage caused by the pest caterpillars: damaged tissues of sunflower heads are affected by pathogens (for

${ }^{*}$ Corresponding author: naducha74@mail.ru 
example, fungi of Alternaria spp., Rhizopus spp.), as a result, the quality of seed material and oil decreases $[7,8]$.

A wide range of physiological and ecological factors influence the harmfulness of $H$. armigera, including high polyphagy, ecological flexibility, high mobility, migration potential, facultative diapause, high fertility, and, especially, the development of resistance to insecticides $[9,10]$.

The natural enemies reduce the $H$. armigera population, but their efficiency is often insufficient to avoid economic damage in case of cultivation of high-value crops [11]. Therefore, the insecticide treatments against pest is essential for protection of sowings of agricultural crops. The control is complicated by the fact that the caterpillars of older instars (4-6 instars) are poorly controlled by insecticides [7, 9]. The frequent use of pesticides develops resistance in insects, for example, resistance to the main chemical insecticide groups in H. armigera is registered in Australia, Asia and Africa, and in Thailand, Turkey, India, Indonesia, and Pakistan, there is noted the resistance to pyrethroids [7, 12]. Consequently, this leads to an increase in dosages and (or) in the usage of new chemicals with high toxicity $[7,13]$. Therefore, the search for reliable means of pest control remains a problem.

The aim of the research was to determine the field efficiency of modern insecticides applied for protection of sunflower sowings against damage by $H$. armigera caterpillars in the Krasnodar region of the Russian Federation.

\section{Materials and methods}

The results of small-plot and production tests of insecticides against Helicoverpa armigera Hbn. on sunflower carried out in 2017-2019 at V.S. Pustovoit All-Russian Research Institute of Oil Crops (Krasnodar) became the material for the article.

We tested the following insecticides: chemical insecticides - Beta-cypermethrin + Dimethoate, EC $(40 \mathrm{~g} / 1+300 \mathrm{~g} / \mathrm{l})-0.15$ 1/ha, Lambda-cyhalothrin + Thiamethoxam, SC $(106 \mathrm{~g} / \mathrm{l}+141 \mathrm{~g} / \mathrm{l})-0.3 \mathrm{l} / \mathrm{ha}$, Bifenthrin + Chlorpyrifos, EC $(20 \mathrm{~g} / \mathrm{l}+400 \mathrm{~g} / \mathrm{l})-1.25 \mathrm{l} / \mathrm{ha}$, Emamectin benzoate, WDG $(50 \mathrm{~g} / \mathrm{l})-0.4$ 1/ha and Chlorantraniliprole, SC (200 g/l) $0.15 \mathrm{l} / \mathrm{ha}$; organic insecticides - Lepidocide (based on Bacillus thuringensis, var. Kurstaki), CS (BA-2000 removal unit/mg, titer at least 10 billion spores/g) - 2 1/ha, Bitoxibacillin (Bacillus thuringensis, var. Huringensis), P (BA-1500 removal unit $/ \mathrm{mg}$, titer at least 20 billion spores/g) - 2 1/ha, Metarizin (Metarhizium anisopliae P-72), LC (titer not less than $1 \times 10^{8} \mathrm{CFU} / \mathrm{ml}$ ) - 2.0 1/ha, and Fitover-M (Aversectin C, $2 \mathrm{~g} / \mathrm{l}$ ), EC - 2.0 1/ha. The variants without treatment served as a control, and the variants with plant treatment with recommended insecticides served as a standard.

We monitored the flying and the imago number of $H$. armigera with pheromone traps produced by AO "Shchelkovo Agrokhim". We carried out all records and calculation of the biological effectiveness of insecticides in accordance with the guidelines for registry testing of insecticides, acaricides, molluscides, and rodenticides in agriculture of the Russian Federation [14].

The number of replications was 3, the plot size in the small-plot experiment was $56 \mathrm{~m}^{2}$, the plot size in the production experiment was 10 ha. We carried out the sowing with a "GASPARDO-MT 8" seeder with a seeding rate of 30.000 viable seeds/ha. We harvested sunflower in the experiments with a "Sampo" harvester, the yield was normalized to $100 \%$ of purity and $10 \%$ of moisture content. We processed the research data by analysis of variance using SPSS software. 


\section{Results and discussion}

The mass flying of imago of Helicoverpa armigera of the overwintered generation under the conditions of 2017 took place at the beginning of the first 10 days of June, in 2018 - at the end of the last 10 days of June, in 2019 - at the beginning of the second 10 days of June and coincided with the budding stage of sunflower (the development stage 53, 55 on the $\mathrm{BBCH}$ scale), the number of butterflies reached 22, 27, and 37 specimen/trap, respectively. The records of pest colonization of heads by H.armigera caterpillars, carried out at the stage of sunflower development 59 on the $\mathrm{BBCH}$ scale, revealed a high number of phytophage - 3.2 specimen/plant in 2017, 4.5 specimen/plant in 2018, and 6.0 specimen/plant in 2019.

The treatment of sunflower plants with insecticides had a positive effect on reducing the number of pests (Table 1).

Table 1. The efficiency of chemical insecticides application in sunflower sowings against Helicoverpa armigera Hbn. caterpillars, V.S. Pustovoit All-Russian Research Institute of Oil Crops, 2017-2018

\begin{tabular}{|c|c|c|c|c|}
\hline Variant & $\begin{array}{c}\text { Application } \\
\text { rate of } \\
\text { preparation, } \\
1 / \text { ha }\end{array}$ & $\begin{array}{c}\text { Biological } \\
\text { effectiveness, } \\
\%\end{array}$ & $\begin{array}{l}\text { Productivity, } \\
\text { t/ha }\end{array}$ & $\begin{array}{l} \pm \text { to } \\
\text { control }\end{array}$ \\
\hline $\begin{array}{l}\text { Control } \\
\text { (without treatment) }\end{array}$ & - & $3.8^{*}$ & 2.30 & - \\
\hline $\begin{array}{l}\text { Beta-cypermethrin + Dimethoate, } \\
\text { EC } \\
(40 \mathrm{~g} / 1+300 \mathrm{~g} / \mathrm{l})(\text { standard })\end{array}$ & 0.15 & 71 & 2.46 & +0.16 \\
\hline $\begin{array}{l}\text { Lambda-cyhalothrin }+ \\
\text { Thiamethoxam, SC } \\
(106 \mathrm{~g} / 1+141 \mathrm{~g} / \mathrm{l})\end{array}$ & 0.3 & 40 & 2.39 & +0.09 \\
\hline $\begin{array}{l}\text { Bifenthrin + Chlorpyrifos, EC (20 } \\
\mathrm{g} / 1+400 \mathrm{~g} / \mathrm{l})\end{array}$ & 1.25 & 87 & 2.61 & +0.31 \\
\hline $\begin{array}{l}\text { Emamectin benzoate, WDG (50 } \\
\mathrm{g} / \mathrm{l})\end{array}$ & 0.4 & 83 & 2.53 & +0.23 \\
\hline $\begin{array}{l}\text { Chlorantraniliprole, SC } \\
(200 \mathrm{~g} / \mathrm{l})\end{array}$ & 0.15 & 91 & 2.70 & +0.40 \\
\hline $\mathrm{HCP}_{05}$ & & & 0.19 & \\
\hline
\end{tabular}

* - the number of caterpillars in control, specimen/plant

The efficiency of chemical insecticides varied from 40 to $91 \%$ in case of average pest colonization of 3.8 specimen/plant in control. We received the best results against H.armigera when plants were treated with Bifenthrin + Chlorpyrifos, EC (87\%) and Chlorantraniliprole, SC (91\%). We observed the smallest decrease in the number of caterpillars in case of application of Lambda-cyhalothrin + Thiamethoxam, SC $-40 \%$.

The ability of insecticides to reduce the pest colonization and damage to the crop by a pest in comparison with the control indicates the level of biological effectiveness of the preparations, and, as a consequence, the preservation of the yield of sunflower seeds. On average, by the experiment variants, the sunflower yield was at the level of 2.30-2.70 t/ha, the kept yield was 0.09-0.40 t/ha. The application of Chlorantraniliprole, SC against the pest resulted in the highest yield in the experiment $-2.70 \mathrm{t} / \mathrm{ha}$.

We also tested organic insecticides to reduce pesticide load and protect sunflower sowings against caterpillars. We determined that, unlike chemical insecticides, organic insecticides did not show their effectiveness immediately. Apparently, it is connected to the 
mechanism of action of bacteria and fungi included in insecticide composition, the exception is Fitoverm-M, which consists of fungi metaplasm. On the $3^{\text {rd }}$ day after the application of organic insecticides, the decrease in the number of caterpillars was very low and varied from 13 to $33 \% \mathrm{~m}$ depending on the variant. On the $14^{\text {th }}$ day, the effectiveness of insecticides was maximum and varied from 31 to $56 \%$ by the variants. The biological effectiveness of Lepidocide (standard) and Bitoxibacillin was at the same level - 35 and 37 $\%$, Fitoverm-M, EC showed the best result in reducing the number of caterpillars $-56 \%$. The economic efficiency of the application of organic insecticides was $2.44-2.48 \mathrm{t} / \mathrm{ha}$ and exceeded the control by $0.08-0.12 \mathrm{t} /$ ha (Table 2 ).

Table 2. The efficiency of organic insecticides application in sunflower sowings against Helicoverpa armigera Hbn. caterpillars, V.S. Pustovoit All-Russian Research Institute of Oil Crops, 2017-2018

\begin{tabular}{|c|c|c|c|c|c|c|}
\hline \multirow[t]{2}{*}{ Variant } & \multirow{2}{*}{$\begin{array}{l}\text { Application } \\
\text { rate of } \\
\text { preparation, } \\
\mathrm{kg} / \mathrm{ha}, \mathrm{l} / \mathrm{ha}\end{array}$} & \multicolumn{3}{|c|}{$\begin{array}{c}\text { Biological effectiveness, } \\
\% \\
\text { (by days after } \\
\text { treatment) }\end{array}$} & \multirow[t]{2}{*}{$\begin{array}{c}\text { Productivity, } \\
\text { t/ha }\end{array}$} & \multirow[t]{2}{*}{$\begin{array}{l} \pm \text { to } \\
\text { control }\end{array}$} \\
\hline & & 3 & 7 & 14 & & \\
\hline Control & $\mathrm{w} / \mathrm{t}$ & $2.1^{*}$ & $3.4^{*}$ & $4.0^{*}$ & 2.36 & - \\
\hline $\begin{array}{l}\text { Lepidocide, CS } \\
\text { (BA-2000 removal } \\
\text { unit/mg, titer at } \\
\text { least } 10 \text { billion } \\
\text { spores/g) (standard) }\end{array}$ & 2.0 & 20.0 & 25.0 & 35.0 & 2.44 & +0.08 \\
\hline $\begin{array}{l}\text { Bitoxibacillin, } \mathrm{P} \\
\text { (BA-1500 removal } \\
\text { unit } / \mathrm{mg} \text {, titer at } \\
\text { least } 20 \text { billion } \\
\text { spores } / \mathrm{g} \text { ) }\end{array}$ & 2.0 & 25.0 & 30.0 & 37 & 2.44 & +0.08 \\
\hline $\begin{array}{l}\text { Metarizin, LC (titer } \\
\text { not less than } 1 \times 10^{8} \\
\text { CFU } / \mathrm{ml})\end{array}$ & 2.0 & 13.0 & 25.0 & 50.0 & 2.46 & +0.10 \\
\hline $\begin{array}{l}\text { Fitoverm-M, EC } \\
(10 \mathrm{~g} / \mathrm{l})\end{array}$ & 2.0 & 33.0 & 56.0 & 56.0 & 2.48 & +0.12 \\
\hline $\mathrm{HCP}_{05}$ & & & & & 0.10 & \\
\hline
\end{tabular}

* - the number of caterpillars in control, specimen/plant

An important stage of the research was the production testing of the best insecticides against H.armigera caterpillars on sunflower. Based on the obtained data, Chlorantraniliprole, SC $(200 \mathrm{~g} / \mathrm{l})$ is the most effective preparation in the small-plot experiments $-0.15 \mathrm{l} / \mathrm{ha}$. We began the production experiment in 2019, sprayed the sunflower sowings at the budding stage (the sunflower development stage 59 on the BBCH scale) using aircraft (AN-2) (Table 3).

Table 3. The efficiency of insecticide spraying of sunflower against Helicoverpa armigera Hbn. caterpillars, V.S. Pustovoit All-Russian Research Institute of Oil Crops, 2019

\begin{tabular}{|l|c|c|c|c|c|}
\hline Variant & $\begin{array}{c}\text { Application } \\
\text { rate of } \\
\text { preparation, } \\
1 / \text { ha }\end{array}$ & $\begin{array}{c}\text { The number } \\
\text { of } \\
\text { caterpillars, } \\
\text { specimen/pla } \\
\text { nt }\end{array}$ & $\begin{array}{c}\text { Biological } \\
\text { effectiveness, } \\
\%\end{array}$ & $\begin{array}{c}\text { Productivity, } \\
\text { t/ha }\end{array}$ & $\begin{array}{c} \pm \text { to } \\
\text { control }\end{array}$ \\
\hline Control & - & 6.0 & - & 2.42 & - \\
\hline Beta-cypermethrin + & 0.15 & 1.7 & 71.7 & 2.65 & +0.23 \\
\hline
\end{tabular}




\begin{tabular}{|c|c|c|c|c|c|}
\hline $\begin{array}{l}\text { Dimethoate, EC } \\
(40 \mathrm{~g} / \mathrm{l}+300 \mathrm{~g} / \mathrm{l}) \\
\text { (standard) }\end{array}$ & & & & & \\
\hline $\begin{array}{l}\text { Chlorantraniliprole, SC } \\
(200 \mathrm{~g} / \mathrm{l})\end{array}$ & 0.15 & 0.2 & 97.0 & 2.81 & +0.39 \\
\hline $\mathrm{HCP}_{05}$ & & & & 0.20 & \\
\hline
\end{tabular}

The experimental data show that the number of $H$. armigera caterpillars in the control variant, on average, was at the level of 6 specimen/plant. The spraying of sowings with insecticides Beta-cypermethrin + Dimethoate, EC (standard) and Chlorantraniliprole, SC contributed to a significant decrease in the number of caterpillars to 1.7 and 0.2 specimen/plant. Accordingly, the biological effectiveness reached 71.7 and $97.0 \%$.

The productivity in the variants with insecticides in the production experiment significantly exceeded the control, the kept yield was 0.23 and $0.39 \mathrm{t} / \mathrm{ha}$.

\section{Conclusions}

The mass flying of Helicoverpa armigera of the overwintered generation took place at the beginning of the first 10 days of June - at the end of the last 10 days of June, and coincided with the budding stage of sunflower, the average number of butterflies reached 22-37 specimen/trap. The records of pest colonization of heads by H.armigera caterpillars revealed a high number of phytophage, 3.2 specimen/plant in $2017,4.5$ specimen/plant in 2018 , and 6.0 specimen/plant in 2019.

The biological effectiveness of the chemical insecticides varied from 40 to $91 \%$. We obtained the best results in the variant with application of Bifenthrin + Chlorpyrifos, EC and Chlorantraniliprole, SC -87 and $91 \%$, respectively. On average, by the experiment variants, the sunflower yield was at the level of 2.30-2.70 t/ha, the kept yield was $0.09-0.40$ t/ha.

The organic insecticides, unlike chemical ones, did not show their effectiveness immediately. We observed the best result on the $14^{\text {th }}$ day after treatment; the insecticide Fitoverm-M, EC showed the highest biological effectiveness - $56 \%$. The yield in the experiment was $2.44-2.48 \mathrm{t} / \mathrm{ha}$ and exceeded the control by $0.08-0.12 \mathrm{t} / \mathrm{ha}$.

In a production experiment, we tested the insecticide Chlorantraniliprole, SC (200 g/l) $0.15 \mathrm{l} / \mathrm{ha}$, which is the most effective against $H$. armigera caterrpillars. The treatment of sowings with Beta-cypermethrin + Dimethoate, EC (standard) and Chlorantraniliprole, SC contributed to a significant decrease in the number of caterpillars - from 6,0 to 1.7 and 0.2 specimen/plant, respectively, while their biological effectiveness reached 71.7 and $97.0 \%$. The productivity in the variants with the preparations significantly exceeded the control, the kept yield was 0.23 and $0.39 \mathrm{t} / \mathrm{ha}$.

\section{References}

1. D.J. Kriticos, N. Ota, W.D. Hutchison, J. Beddow, T. Walsh, W.T. Tay, D.M. Borchert, S.V. Paula-Moreas, C. Czepak, M.P. Zalucki, PLoS ONE, 10(7) (2015)

2. S. Soleimannejad, Y. Fathipour, S. Moharramipour, M.P. Zalucki, Economic Entomology V 103, 4, 1420-1430 (2010)

3. D.R. Sosa-Gómez, A. Specht, S.V. Paula-Moraes, A. Lopes-Lima, S.A.C. Yano, A. Micheli, E.G.F. Morais, P. Gallo, R.V.S. Pereira, J.R. Salvadori, M. Botton, M.M. Zenker, W. S. Azevedo-Filho, Revista Brasileira de Entomologia 60, 101-104 (2016)

4. J.P. Cunningham, M.P. Zalucki, Economic Entomology, 107, 881-896 (2014) 
5. W.T. Tay, M.F. Soria, Th. Walsh, D. Thomazoni, P. Silvie, G.T. Behere, C. Anderson, Sh. Downes, PLoS ONE, 8(11) (2013)

6. D. N. Govorov, V. A. Alive,M. Y. Proskuryakov, Protection and quarantine of plants 5, $18-20(2013)$

7. V. M. Lukomets, N. I. Bochkarev, N. M. Tishkov, S. A. Semerenko, N. A. Bushneva, Cotton cutworm in sunflower agrocenosis, development features, methods of detection and control measures (2019)

8. I. I. Shulyak, N. V. Muradasilova, Oil crop, 1(165), 100-105 (2016)

9. L.M. Torres-Vila, M.C. Rodríguez-Molina, A. Lacasa-Plasencia, P. Bielza-Lino, Crop Protection V. 21, 10, 1003-1013 (2002)

10. V.N. Cherkashin, A.N. Malykhina, G.V. Cherkashin Agriculture, 5, 35-36 (2014)

11. L.M. Torres-Vila, M.C. Rodríguez-Molina, E. Palo, P. Del Estal, A. Lacasa, Agriculture, ecosystems, 26, 323-333 (2002)

12. K.R. Kranthi, D.R. Jadhav, S. Kranthi, R.R. Wanjari, S.S. Ali, D.A. Russell, Crop Protection V. 21, 6, 449-460 (2002)

13. R.C. Duprat, M.C. Anholeti, B.P. de Sousa, J.P.F.Pacheco, M. R. Figueiredo, M.A.C. Kaplan, M. Guerra Santos, M.S. Gonzalez, N. A. Ratcliffe, C.B. Mello, S. R. Paiva, D. Feder, Revista Brasileira de Farmacognosia V. 27, 1, 59-66 (2017)

14. V. I. Dolzhenko, Guidelines for registration testing of insecticides, acaricides, molluscicides and rodenticides in agriculture (2009) 